\title{
RECURRENT BASAL CELL CARCINOMA TREATED WITH CRYOSURGERY
}

\author{
Ranjeeta Sapam 1 , Y. Lokendro'2, Julie Leishangthem³, Sarda Okram4, Chitralekha Keisham ${ }^{5}$
}

${ }^{1}$ Associate Professor, Department of Dermatology, JNIMS, Porompat, Imphal.

${ }^{2}$ Assistant Professor, Department of Dermatology, JNIMS, Porompat, Imphal.

${ }^{3}$ Senior Resident, Department of Dermatology, JNIMS, Porompat, Imphal.

${ }^{4}$ Senior Resident, Department of Dermatology, JNIMS, Porompat, Imphal.

5 Senior Resident, Department of Dermatology, JNIMS, Porompat, Imphal.

\section{ABSTRACT}

There are reports of treatment of primary BCC by cryosurgery; however, very few data are available on the successful treatment of recurrent BCC by cryosurgery.

\section{KEYWORDS}

BCC, Cryosurgery, Ulcer.

HOW TO CITE THIS ARTICLE: Sapam R, Lokendro Y, Leishangthem J, et al. Recurrent basal cell carcinoma treated with cryosurgery. J. Evolution Med. Dent. Sci. 2016;5(25):816-817, DOI: 10.14260/jemds/2016/188

\section{INTRODUCTION}

BCC is one of the most prevalent forms of cancer worldwide. Although, there are reports of cure rates achieved by cryosurgery for primary BCC, very few data are available on treating recurrent $\mathrm{BCC}$ by it.

\section{CASE HISTORY}

A 50-year-old female presented to our OPD with a clinical history of a gradually enlarging painless ulcer in the face since the last one year. Clinical examination showed a well-to-illdefined ulcer of size $7 \times 5 \mathrm{~cm}$ in the left cheek extending from the middle of the cheek to the lower eyelid. The margin is erythematous, indurated and rolled. Pigmentation is seen in few areas. The floor of the ulcer is irregular and few areas spotted with necrotic tissue. On palpation, the base was indurated and nontender.

Histopathological examination showed a malignant tumour composed of cells arranged in lobules infiltrating the dermis. Cells at the periphery showed a palisading appearance. Individual tumour cells are basaloid having a scanty cytoplasm and hyperchromatic nuclei. Clefting was seen in between the lobules. Resected margin was free of lesion.

Clinical diagnosis of basal cell carcinoma was confirmed with histopathological findings. Wide surgical excision followed by skin grafting was done. After a symptom free period of 1 year, the patient came back with local recurrence. Cryosurgery was performed. Duration of the freezing was 2-3 minutes with tissue temperature of -180 degree $C$, the lateral spread of frost measured $5 \mathrm{~mm}$ beyond the obvious limits of the tumour. Tissue was permitted to thaw for 5 minutes. Three cycles were performed. With proper post-operative care, an eschar was formed in 1 week and wound healing occurred in 8 weeks. Patient is symptom free for 1 year after cryosurgery.

Financial or Other, Competing Interest: None

Submission 30-12-2015, Peer Review 05-02-2016,

Acceptance 13-02-2016, Published 25-02-2016.

Corresponding Author:

Dr. Ranjeeta Sapam,

Moirangkhom Sougaijam Leirak,

Imphal.

E-mail: ranssapam@gmail.com

DOI: $10.14260 /$ jemds/2016/188

\section{DISCUSSION}

Basal Cell Carcinoma (BCC) is the most common cancer in individuals with fair skin type and steadily increasing in incidence.1,2,3 Treatment options for localized resectable BCC include micrographically controlled surgery, simple excision, curettage, laser ablation, cryosurgery, imiquimod, 5fluorouracil, photodynamic therapy and radiotherapy. ${ }^{4}$ Standard therapy is complete surgical removal. ${ }^{5}$ Surgical treatment of BCC can be technically difficult in mid-face area leading to recurrence of the lesion. Recurrent BCC may develop at any time either different or similar to the primary tumour. ${ }^{6}$ Various treatments are available, however, needs individualization. Cryosurgery is proposed for low-risk BCC. Cryosurgery has been poorly investigated in mid-face BCC, which is considered as having a high risk of recurrence. ${ }^{7}$ Cure rates up to $98 \%$ have been reported after cryosurgical treatment of primary BCC. ${ }^{8}$ Reports concerning cryosurgical treatment of recurrent $\mathrm{BCC}$ are sparse. It is well known that the cure rate for recurrent lesions with any modality is lower than for primary tumour; cryosurgery is no exception. ${ }^{9}$ Cryosurgery is an effective treatment modality for eyelid basal cell carcinomas, resulting in a few recurrences and good cosmetic and functional outcomes at a low cost. ${ }^{10}$ Cryosurgery can be an alternative choice for management of small-to-medium sized recurrent BCC if done aggressively with proper delineation of depth and width. ${ }^{9}$

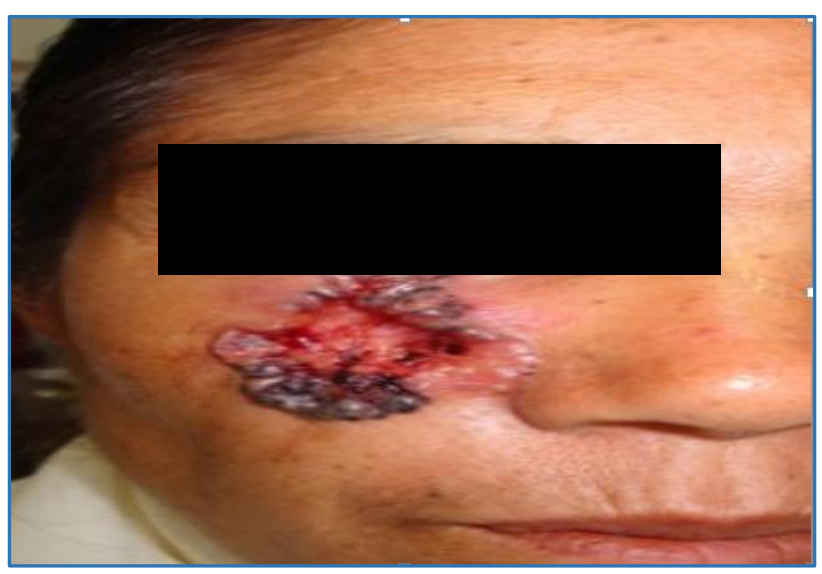

Fig. 1: Pic Showing BCC Extending from cheek to the Lower Eyelid c 


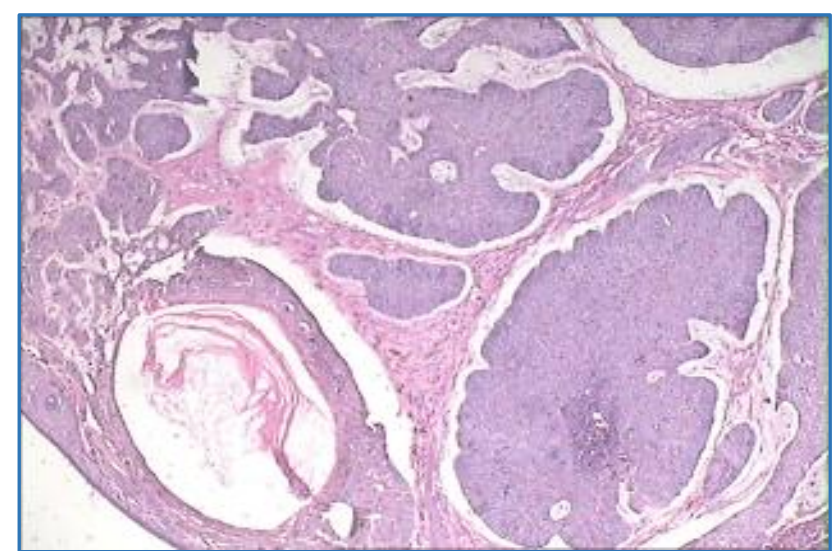

Fig. 2: HPE Findings

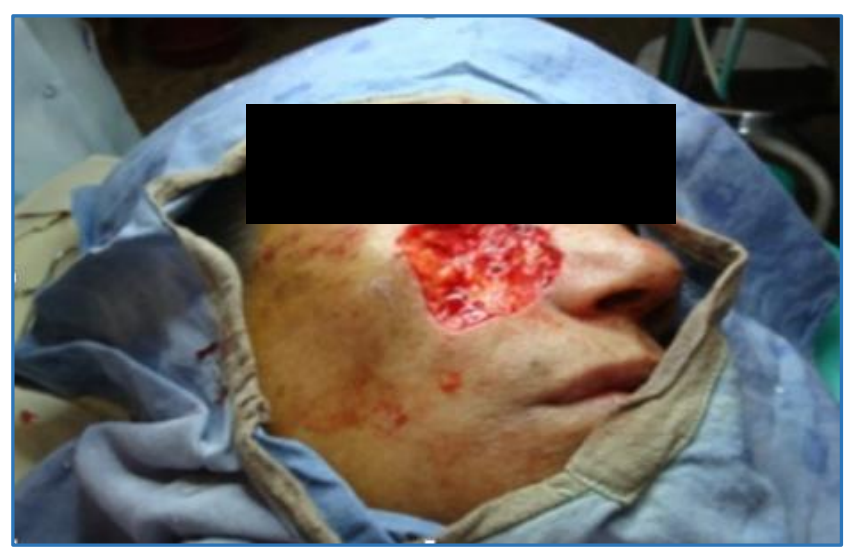

Fig. 3: Wide Excision C

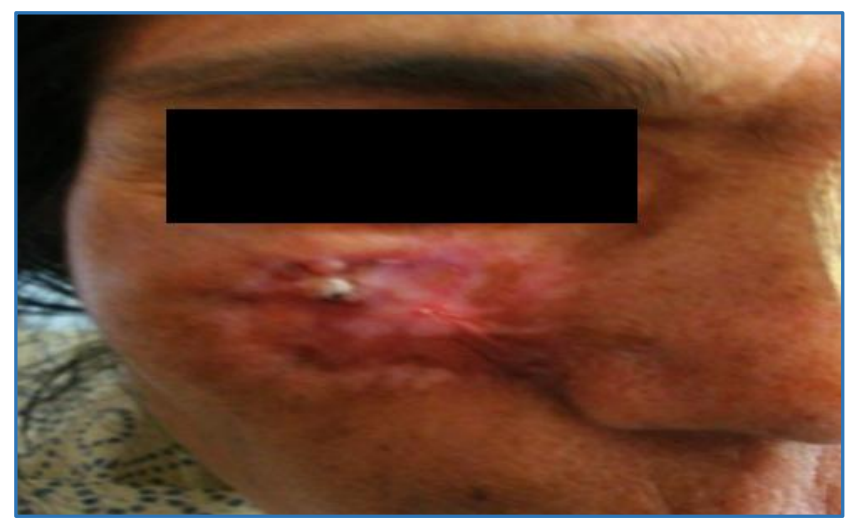

Fig. 4: Recurrence C

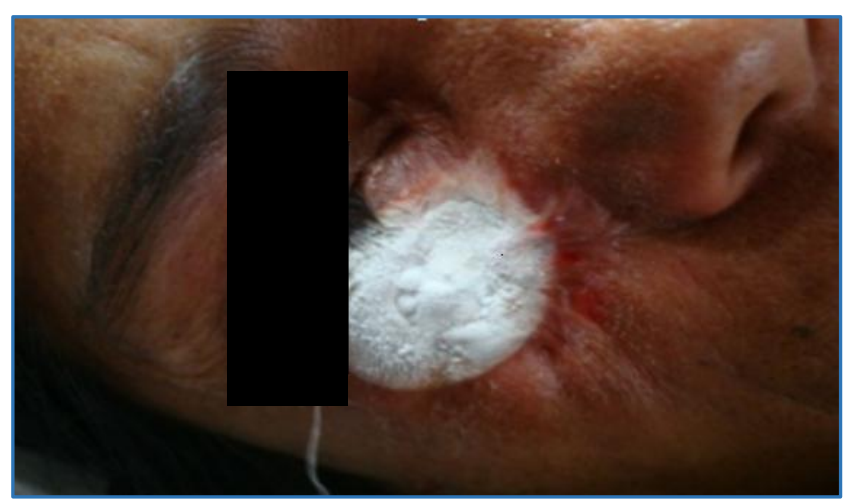

Fig. 5: Immediately after Cryosurgery C

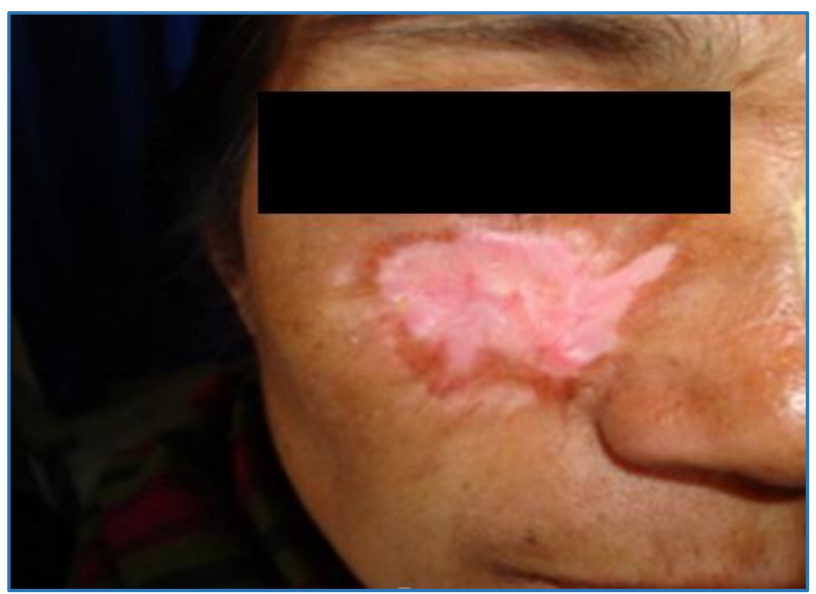

Fig. 6: One Year after Cryosurgery C

\section{REFERENCES}

1. Lomas A, Leonardi-Bee J, Bath-Hextall F. A systematic review of worldwide incidence of non-melanoma skin cancer. Br J Dermatol 2012;166:1069-80.

2. Karagas MR, Greenberg ER, Spencer SK, et al. Increase in incidence rates of basal cell and squamous cell skin cancer in New Hampshire, USA. New Hampshire Skin Cancer Study Group. Int J Cancer 1999;81:555-9.

3. Christenson LJ, Borrowman TA, Vachon CM, et al. Incidence of basal cell and squamous cell carcinomas in a population younger than 40 years. JAMA 2005; 294:681-90.

4. Isabelle Martin, Marthe-Lisa S, Anne G, et al. Patient preferences for treatment of basal cell carcinoma: importance of cure and cosmetic outcome. Acta Derm Venereol 2015;96:1-6.

5. Berking C, Hauschild A, Kölbl O, et al. Basal cell carcinoma-treatments for the commonest skin cancer. Dtsch Arztebl Int 2014;111:389-95.

6. Samain A, Boullié MC, Duval-Modeste AB, et al. Cryosurgery and curettage-

cryosurgery for basal cell carcinomas of the mid-face. J Eur Acad Dermatol Venereol 2015;29(7):1291-6.

7. Koplin L and Zarem HA. Recurrent basal cell carcinoma: a review concerning the incidence, behaviour and management of recurrent basal cell carcinoma with emphasis on the incompletely excised lesion. Plast Reconstr Surg 1980;65: pp. 656-664.

8. Koplin L and Zarem HA. Recurrent basal cell carcinoma: review concerning the incidence, behaviour and management of recurrent basal cell carcinoma with emphasis on the incompletely excised lesion. Plast Reconstr Surg 1980;65: pp. 656-664.

9. Zacarian SA. Cryosurgery of cutaneous carcinomas: an 18-year study of 3022 patients with 4228 carcinomas. J Am Acad Dermatol 1983;9: pp. 947-956.

10. Lang PG and Maize JC. Basal cell carcinoma. In: Friedman RJ, Rigel DS, Kopf AW, et al. Editors, Cancer of the skin, WB Saunders, Philadelphia (1991), pp. 57-58. 